\title{
Shelf-life Prediction Modeling and Physicochemical Changes of Canned African Giant Snail (Achachatina achatina) Based Products during Storage Using Sensory and Kinetic Data
}

\author{
Elizabeth Ugbede-Ohuoba ${ }^{1}$, Thomas M. Okonkwo ${ }^{2}$, Iro Nkama ${ }^{2}$, J. I. Eze ${ }^{2}$ \& Samaila James ${ }^{1}$ \\ ${ }^{1}$ Department of Food Science and Technology, Federal University of Technology, Minna, Nigeria \\ ${ }^{2}$ Department of Food Science and Technology, University of Nigeria, Nsukka, Nigeria \\ Correspondence: Elizabeth Ugbede-Ohuoba, Department of Food Science and Technology, Federal University of \\ Technology Minna, Nigeria. E-mail: e.ohuoba@futminna.edu.ng
}

Received: February 8, 2020

Accepted: January 13, $2021 \quad$ Online Published: February 12, 2021

doi:10.5539/jfr.v10n2p11

URL: https://doi.org/10.5539/jfr.v10n2p11

\begin{abstract}
Canned African giant snails (brine, egusi and sauce) of low acidity ( $\mathrm{pH} 4.5)$ were produced using Thermal Death Time (TDT) techniques. Sixty cans of each product were stored for 6 months at normal temperature $\left(30^{\circ} \mathrm{C}\right)$. The physicochemical and sensory properties of these products were evaluated monthly. And also, 28 cans of each product were equally evaluated at accelerated storage temperatures stress $\left(50,60,70 \& 80^{\circ} \mathrm{C}\right)$ for 6 weeks. Changes in $\mathrm{pH}$ and overall acceptability were described by first and second order kinetics respectively. The extent of proteolysis, peroxidase activities, and extent of fat hydrolysis i.e peroxide and thiobabituric acid values did not change significantly $(\mathrm{P}>0.05)$ during storage. Regression analysis was used to fit models for Gibbs free energy of activation for physicochemical changes as a function of temperature and to predict models for overall acceptability as a function of $\mathrm{pH}$. Shelf-life prediction models were fitted based on sensory and $\mathrm{pH}$ kinetic data. Shelf-lives of 27.6 months, 27-25 months and 18-16.8 months were estimated for snail in brine (SIB) snail in egusi (SES) and snail in sauce (SIS) respectively during storage at $30^{\circ} \mathrm{C}$.
\end{abstract}

Keywords: snails, unconventional, cholesterol, canning, Clostridium botulinum, physicochemical changes

\section{Introduction}

African giant Snail (Achachatina achatina) is a terrestrial shell bearing animal of approximately 100,000 species of molluscs grown in the forest region of Nigeria and other countries in the humid /Semi Arid region of Africa. Snail is an unconventional source of cheap and affordable animal protein that is required for growth and repairs of body tissues .Inadequate supplies and high shortages of food in the world, particularly in developing countries necessitate the search for new sources of food (Mahala \& Mohhammed, 2010). According to Ariahu (2012), the conventional meat sources such as beef, broiler meat, goat meat, mutton, pork and horse meat, have high amount of cholesterol and fatty acid contents. Nutritionally, the African giant snail has high content of iron, phosphorus and calcium; hence, it is useful in treatment of anemia, hypertension and other fat related diseases.

Previous studies on African giant snail in Nigeria have reported that, snail rearing operations can be approached with much convenience, since the business could be accommodated within a family backyard and are often eaten cooked in stew or soups or fried as snacks once they are harvested. The implications of this, is that, the African giant snail lacks long term preservation techniques such as canning, irradiation, dehydration, or even use of low temperatures (e.g. freezing and refrigeration). Canning offers convenience for retail and consumer handling without dependence on low/ erratic power supply as witnessed in developing countries. Snails require adequate processing in order to ensure its preservation and keeping qualities.

The production of canned snails needs the commercial sterilization of the meat in metal or glass containers by the application of the "Botulinum cook". This is the minimum heat treatment that all low acid foods (pH>5) must receive in order to assure safety from Clostridium botulinum. Commercial sterility is normally verified by inoculated pack studies (Ariahu et al., 2004).

During storage of commercially sterile low acid foods, physicochemical reactions may occur. These reactions may lead to changes in sensory and nutritional qualities such as taste, aroma, colour, proteolysis, loss of vitamins 
and break down of carbohydrates. Changes in physicochemical properties of commercially sterile products during storages may be a treat to its shelf-life, more than microbiological activities. Shelf-fife of a food product is the period before microbiological, physical, chemical or sensory qualities deteriorate beyond a set of limit (Ismail et al., 1996). Reaction kinetics may be applied to quantify and predict extent of physicochemical changes during processing and storage of foods (Rustom et al., 1996).

Information on changes in the physicochemical parameters of the African giant snail in various media during canning and sterilization and the shelf-life prediction models are lacking. The general objective of this study was to make the African giant snail available in ready-to-eat forms that are safe from the public point of view.

The specific objectives of this study were to produce canned snail-in-brine, snail-in-sauce and snail-in-egusi soup products, develop shelf-life prediction models for the products and also to analyse its physicochemical changes during storage based on sensory and kinetic data.

\section{Materials and Methods}

\subsection{Sample Collection}

Locally grown African giant snails (Achachatina achatina) of $300 \mathrm{~g}$ average weight were purchased from a local market (Ogige market) in Nsukka Nigeria. About $18 \mathrm{~kg}$ of the mollusc were transported to the laboratory in moistened jute bags. After cracking the shells, the meats were removed, washed with $5 \%$ alum solution to remove slime, packaged in polythene bags and kept under frozen storage $\left(-18^{\circ} \mathrm{C}\right)$ until utilized.

Lacquered 208 x 300 round sanitary cans and lids were donated by Metal Box Nigeria Limited, Oshodi, Lagos.

\subsection{Media Formulation and Selection}

Egusi soup and a sauce were prepared as described by Vincent (1980). The egusi soup was prepared from fresh pumpkin leaves, ground melon seeds, pepper, salt, fermented locust bean, onion and palm vegetable oil. The sauce consisted of tomatoes, pepper, salt, fresh onions, vegetable oil, neutralized hydrolyzed vegetable protein (Maggi cubes, Nestle Foods Plc., Lagos Nigeria) and pure water. The brine consisted of $0.5 \%$ sodium tripolyphosphate and $4 \%$ table salt and potable water.

The $\mathrm{pH}$ of each formulation was varied from 5.7 to 7.9 with citric acid. The sauce, egusi soup or brine selection was done by a preliminary sensory evaluation which suggested that products with an equilibrium $\mathrm{pH}$ of 6.9 had optimum quality based on flavour and appearance. The flow charts for the production of the various canned snail products are shown in Figures 1, 2 and 3 below.

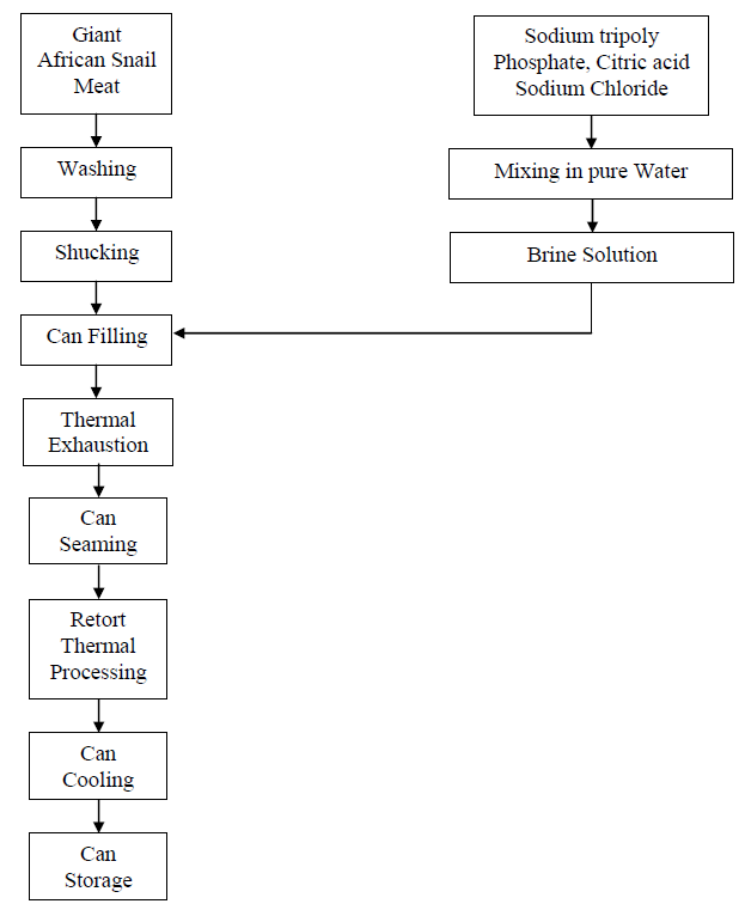

Figure 1. Flow chart for the production of canned African giant snail in brine (Ariahu et al., 2012) 


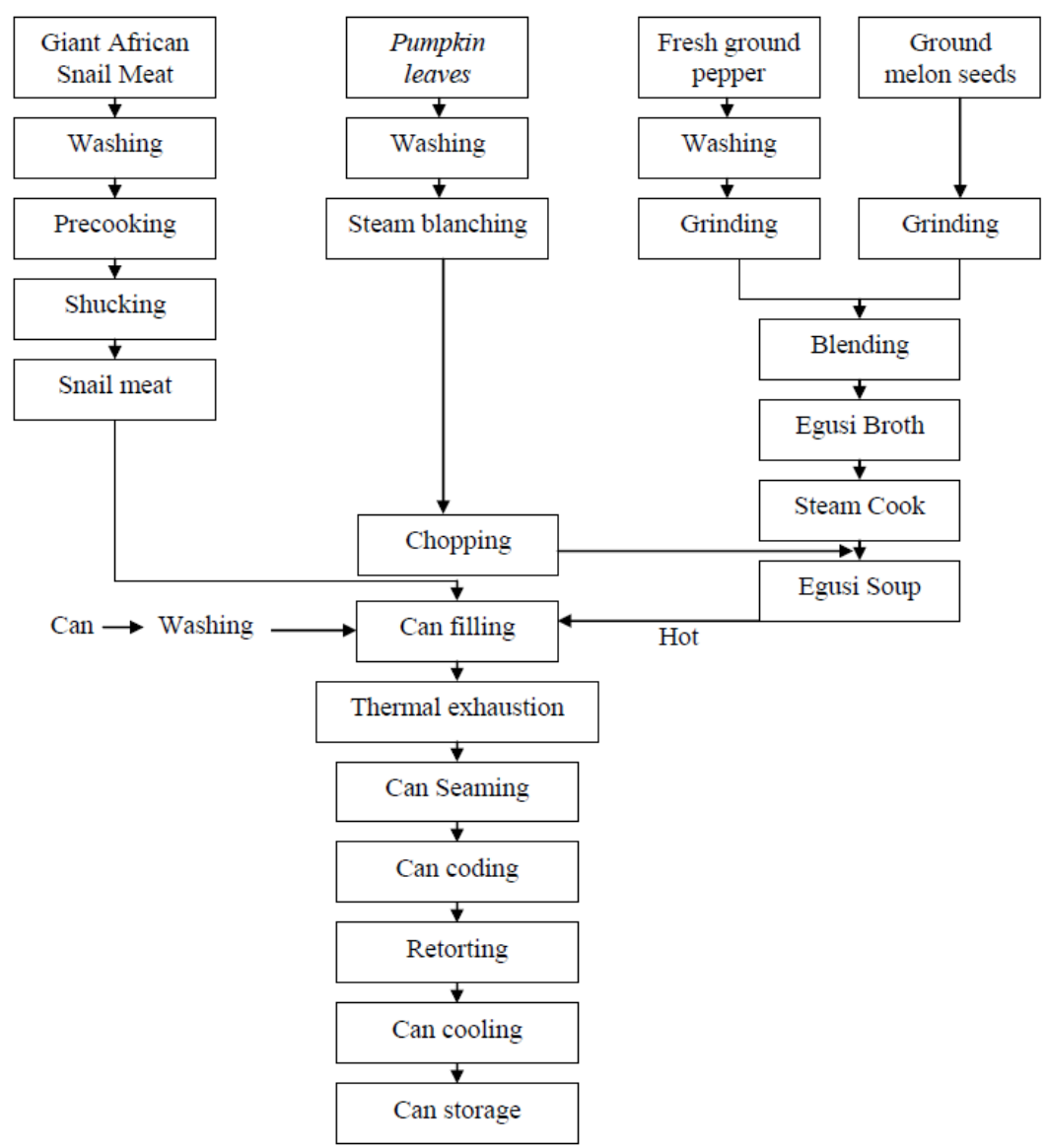

Figure 2. Flow chart for the production of canned snail - in - egusi soup

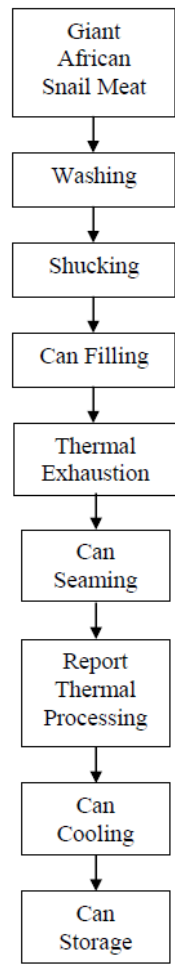

Figure 3. Flow chart for the production of canned snail - in - sauce 


\subsection{Heat Resistance of Microorganisms}

The $208 \times 300 \mathrm{~L} / \mathrm{L}$ round sanitary cans were aseptically filled with lobes of snail meat $(160 \mathrm{~g} / \mathrm{can})$. The abductor muscles in each can were infected with a $1 \mathrm{ml}$ spore suspension by multiple injection using a disposable hypodermic syringe and needle. Enough cooking brine or sauce or egusi soup was then added to a fill-in weight of $250 \mathrm{~g}$ which yielded about $10^{6}$ spores/can of each product. After gentle agitation to eliminate air bubbles, the cans head spaces were thermally exhausted $(10 \mathrm{~min})$ using saturated steam followed by steaming with a semiautomatic can seaming machine.

Thermal resistance was determined at four times intervals $(5,10,15,20$ minutes) at temperatures of 104.4, 110, 115.6 and $121.1^{\circ} \mathrm{C}\left(220,230,240\right.$ and $\left.350{ }^{\circ} \mathrm{F}\right)$ for each product. For each time interval, fourteen cans were prepared, ten heated and four used as control. The cans were heated in a laboratory scale batch retort (Mill walls, J.S. Fraser and Sons, London) equipped with an automatic temperature control. Before each run, the retort was vented for 10 mins. Come-Up-Times (CUT) were determined using plug-in copper-constantan thermocouples $(0.1 \mathrm{~mm}$ diameter needles) with the probes carefully placed inside the muscles at central axis for at least three cans for each product.

\subsection{Microbiology}

The cans were opened aseptically after flooding the lids with a $100 \mathrm{ppm}$ chlorine solution as recommended by Deny (1972). The contents of each sample was transferred into a sterile mixer and diluted ten-fold by weight with sterile water. The resulting mixture was macerated $(4 \mathrm{~min})$ and neutralized with $4 \mathrm{M} \mathrm{NaOH}$ solution. Serial ten-fold dilutions were made in liver broth and the surviving spores counted with the aid of the 5-tube Most Probable Number (MPN) technique (Mayou, 1976). The tubes were incubated at $30^{\circ} \mathrm{C}$ for 15 days together with their controls. Positive growth was identified by turbidity and gas and was confirmed to be due to C. sporogenes using series of cultural and biochemical tests described by Nigerian Canners Association.

\subsection{Thermal Data Analysis}

The decimal reduction times $\left(\mathrm{D}_{\mathrm{T}}\right)$ were calculated by the partial sterilization technique (Stumbo, 1973) from:

$$
\mathrm{D}_{\mathrm{T}}=\mathrm{t}\left(\log \mathrm{N}_{0}-\log \mathrm{N}\right)
$$

where $\mathrm{t}$ is the heating time at temperature, $\mathrm{T}\left({ }^{\circ} \mathrm{C}\right) ; \mathrm{N}_{0}$ is initial number of microorganism spores/sample multiplied by the number of replicate samples and $\mathrm{N}$ is MPN of microorganism spores which survived. The $\mathrm{D}_{\mathrm{T}}$ values (i.e., the times required to reduce the $C$. sporogenes spores population in each product by $90 \%$ at the various temperatures) were described as direct exponential function of temperatures:

$$
\log \mathrm{D}_{1} / \mathrm{D}_{2}=\left(\mathrm{T}_{2}-\mathrm{T}_{1}\right) / \mathrm{z}
$$

where $D_{1}$ and $D_{2}$ are decimal reduction times at temperature $T_{1}$ and $T_{2}$ respectively with $z$ (negative reciprocal slope of the TDT curve) representing slope index of the line generated via least square linear regression.

\subsection{Physicochemical Analysis}

\section{$2.6 .1 \mathrm{pH}$}

The $\mathrm{pH}$ was measured at $30 \pm 1^{\circ} \mathrm{C}$ with an electronic $\mathrm{pH}$ meter (M62, Radiometer, Copenhagen, Demark). Duplicate samples $(10 \mathrm{~g}$ each) of product were macerated with $40 \mathrm{~mL}$ chilled phosphate buffer $(\mathrm{pH}=6.88)$ for 5 minutes in a household electric blender. The $\mathrm{pH}$ of the homogenate was measured using a previously referenced electrode of the $\mathrm{pH}$ meter.

\subsubsection{Proximate Analysis}

The proximate compositions of the canned products were determined by AO AC (2010) standard procedure 14.064 for moisture content, 14.067 for protein. Carbohydrate was calculated by difference. Energy values were estimated by the Atwater factor method (4xg protein:, 9xg fat and 4xg carbohydrate).

\subsubsection{Extent of Proteolysis}

The total nitrogen (TN) in each product was fractionated into non-protein nitrogen (NPN) and protein nitrogen (isoelectric precipitate). Extent of proteolysis was calculated from the difference between relative amounts of NPN to TN as percentage at 0 and 24 weeks Storage. NPN was determined according to a modification of the procedure described by Ismail et al. (1996). About $10 \mathrm{~g}$ of each product was diluted $(1: 10, \mathrm{w} / \mathrm{w})$ with distilled water and blended using a household electric blender. The $\mathrm{pH}$ was adjusted to 4.6 (with $1 \mathrm{M} \mathrm{HCl}$ ) to precipitate protein. The nitrogen in the original sample (TN) and in the supernatant (NPN) was determined with a kjeltic Auto 1030 Analyzer (Tecator AB, Hoganas, Sweden). 


\subsubsection{Peroxidase Activity}

Peroxidase activity was measured by the method described by Adams (1978).Assays were performed on samples $(10-100 \mathrm{mg})$ of the homogenate weighed directly into a spectrophotometer (Spectro-20) sample cuvette without prior extraction of the peroxidase.Two $\mathrm{ml}$ of acetate buffer ( $\mathrm{pH}$ 5.6) was then pipette into the cuvette which was shaken and held for 5 mins at $30^{\circ} \mathrm{C}$ in a constant temperature bath. $0.7 \mathrm{~mL}$ of substrate $(0.5 \%$ guaiacol $+0.1 \%$ hydrogen peroxide in acetate buffer, mixed 1:1) was added and the assay carried out with the reference cuvette containing an equal weight of homogenate shaken in $2.7 \mathrm{~mL}$ of acetate buffer. The absorbance of brown colour formed was measured at $420 \mathrm{~nm}$ against the blank. Peroxidase activity was expressed in terms of maximum rate of increase in absorbance (Usually 20 minutes).

\subsubsection{Extent of Fat Hydrolysis}

Peroxide and thiobarbituric acid (TBA) values were determined as described by Pearson (1976). For peroxide value, ten grams of each prepared sample were weighed into a Kenwood blender followed by $8 \mathrm{~mL}$ of distilled water, $20 \mathrm{~mL}$ of methanol, $10 \mathrm{~mL}$ of chloroform and $0.1 \mathrm{~mL}$ of butylated hydroxyl toluene (BHT). The mixture was blended for 2 mins. $10 \mathrm{~mL}$ of chloroform was then added followed by blending for 30 seconds. Additional $10 \mathrm{~mL}$ of distilled water was added followed by homogenization for 30 seconds. The resultant mixture was then filtered with Buchner-filter under wet vacuum and the filtrate transferred to a separator funnel. After allowing the filtrates to settle for about $10 \mathrm{mins}$, the lower fracture was transferred to a weighed flask. $5 \mathrm{ml}$ of the organic solvent 'extract were evaporated on a steam bath and the amount of fat recorded

Peroxide values were estimated on $0.5 \mathrm{~g}$ extracted fat as follows: to $0.5 \mathrm{~g}$ of extracted fat in $250 \mathrm{~mL}$ Erlenmeyer flasks were added $30 \mathrm{~mL}$ acetic chloroform solution $(1: 1 \mathrm{v} / \mathrm{v})$ and the flasks swirled until samples dissolved, then $0.5 \mathrm{~mL}$ of saturated potassium iodide(KI) was added to each flask and the solutions allowed to stand for exactly 1 minute. $30 \mathrm{~mL}$ of distilled water were then added and the solutions titrated gently with $0,1 \mathrm{M}$ with constant shaking to a very faint yellow colour. $0.5 \mathrm{~mL}$ of starch indicator was then added and the titrations continued with vigorous shaking near the end point to liberate all the iodide from the chloroform layer. Several drops of the thiosulphate solution were added until the blue colour vanished.

$$
\text { Calculations: } \frac{\text { S X M X } 100}{\text { Weight of sample }}
$$

Where: $\mathrm{S}=\mathrm{mL}$ of thiosulphate; $\mathrm{M}=$ molarity of $\mathrm{Na}_{2} \mathrm{~S}_{2} \mathrm{O}_{3}$ solution.

For thiobarbituric acid, $10 \mathrm{~g}$ of each prepared food sample were macerated with $50 \mathrm{~mL}$ of distilled water for 2 mins. The macerate was then washed into a distillation flask with $47.5 \mathrm{~mL}$ distilled water and $2.5 \mathrm{~mL}$ of $4 \mathrm{M} \mathrm{HCl}$ added .A few beads of anti bumps of glass were added and the flask heated in an electric mantle (1000 volts). 50 $\mathrm{mL}$ of the distillate was collected after boiling began within 10 mins. Then $5 \mathrm{~mL}$ of each distillate was pipette into a glass-stoppered tube followed by $5 \mathrm{~mL}$ thiobarbituric acid reagent $(0.2883 / 100 \mathrm{~mL}$ of $90 \%$ glacial acetic acid). The tubes were tightened, shaken and heated in boiling water for 35 mins. A blank was prepared similarly using $5 \mathrm{~mL}$ distilled water and $5 \mathrm{~mL}$ of the reagent. The tubes were cooled in water for $10 \mathrm{~min}$ and the optical densities measured against the blank at $53 \mathrm{~nm}$ using $1 \mathrm{~cm}$ cells in a spectroplus spectrophotometer.

Thiobarbituric acid No. (mg malonaldehyde/1000g sample): $=7.8 \mathrm{D}$

Where: $\mathrm{D}=$ optical densities.

\subsubsection{Drained Weights}

The drained weights of each product was determined according to the United States Department of Agriculture (USDA) standard method as reported by Lopez (1988).Essentially it was performed by emptying the contents of product can evenly upon an 8 -mesh screen $(2.5 \mathrm{~mm}$ opening) and inclining of the sieve at an angle of about 30.Exactly 2 mins after placing on the screen, the drained solids were weighed by placing the screen containing the drained solids directly on a balance and weighing. The weight of the draining screen was then subtracted to obtain drained weight of the product.

\subsection{Sensory Evaluation}

Sensory evaluation was performed using descriptive analysis and affective testing (Stone and Sidel, 1985). Forty panelists participated. The panelists consisted of staff members and graduate students from the Department of Food Science and Technology, University of Nigeria, Nsukka. A 5-point unstructured descriptive scale was used to rate attribute of sensory appearance $(1=$ bright, $5=$ dark $)$, taste $(1=$ bad, $5=\operatorname{good})$, bitterness $(1=$ no bitter after-taste, 5 = strong bitter after-taste). Perception of off-flavors was judged quantitatively as "present" or 
"absent". The panelists asked to identity off-flavors as rancid, putrid, or others. A 7-point structured hedonic scale $(1=$ dislike extremely, $4=$ neither like nor dislike, $7=$ like extremely $)$ was used to score overall acceptability of the canned products. The panels were conducted under fluorescence light in a special room. The three products were judged on monthly basis by each of the panelists. Slices of the snail meat with the brine, sauce or egusi soup were served in $100 \mathrm{ml}$ colorless transparent plastic cups coded with 4-digit random numbers. Colorless plastic spoons were also provided. About $25 \mathrm{~g}$ sample was served warm $\left(40-50^{\circ} \mathrm{C}\right)$. Fresh water was provided to rinse between evaluations.

\subsection{Statistical Analysis}

STATGRAPHICS software (STATGRAPHICS, 1991) was used (multivariate methods module) to calculate Pearson product-moment correlation coefficients between sensory attributes and physicochemical properties. Regression analysis (Kramer and Twigg, 1970) was used to fit models for Gibb's free energy of activation for physicochemical changes as a function of temperature and to predict models for overall acceptability as a function of $\mathrm{pH}$. Significant $(\mathrm{p}<0.05)$ differences in chemical composition and kinetic data were determined by analysis of variance (Kramer and Twigg, 1970). Tukey's tests as described by Ihekoronye and Ngoddy (1985) were used for separating the means.

\subsection{Kinetics and Thermodynamic Calculations}

Simplifying assumptions were made for calculation of kinetic parameters of physicochemical changes in the canned products during storage. Irreversible, non cyclic, unimolecular reaction mechanism (A- $\mathrm{f} B$ ) was assumed for all physicochemical changes.

Reaction order for change in physicochemical parameters at constant temperatures was calculated (Ariahu and Ogunsua, 2000) with the following equation (4):

$$
\mathrm{dC} / \mathrm{dt}= \pm \mathrm{kC}^{\mathrm{n}}
$$

where $\mathrm{C}=$ value of physicochemical parameters at time, $\mathrm{t}\left(\right.$ weeks), $\mathrm{k}=$ reaction rate constant $\left(\mathrm{wk}^{-1}\right), \mathrm{n}=$ reaction order.

Reaction rate constant was calculated by linear regression using equation (5)

$$
\mathrm{C}_{0}-\mathrm{C}=\mathrm{kt}
$$

for zero order reactions and, equation (6)

$$
\ln \left(\mathrm{C}_{0} / \mathrm{C}\right)=\mathrm{kt}
$$

for first order reactions with $\mathrm{C}_{0}$ - initial value of physicochemical parameter.

Temperature dependence of the rate constant was expressed by Arrhenius equation:

$$
\mathrm{k}=\mathrm{k}_{\mathrm{o}} \exp .(\mathrm{Ea} / \mathrm{RT})
$$

where $\mathrm{k}_{0}=$ frequency factor (independent of temperature), $\mathrm{E}_{\mathrm{a}}=$ activation energy $(\mathrm{kJ} / \mathrm{mol}), \mathrm{R}=$ universal gas constant $\left(0.008314 \mathrm{~kJ} / \mathrm{mol}^{\circ} \mathrm{K}\right), \mathrm{T}=$ absolute temperature $\left({ }^{\circ} \mathrm{K}\right)$.

\section{Results and Discussion}

\subsection{Proximate Composition of the African Giant Snail Meat}

The proximate composition of the canned snail in brine (SIB), snail in sauce (SIS) and snail in egusi soup (SES) products are shown in Table 1 . The crude protein ranged from $89.3 \mathrm{~g} / 100 \mathrm{~g}$ solids, solids for snail in brine to 90.1 $\mathrm{g} / 100 \mathrm{~g}$ solids for snail in sauce product. The fat content varied from $2.0 \mathrm{~g} / 100 \mathrm{~g}$ solids in snail in brine to 5.0 $\mathrm{g} / 100 \mathrm{~g}$ solids for snail in egusi soup. The ash contents were 1.6, 1.6 and $1.5 \mathrm{~g} / 100 \mathrm{~g}$ solids for SIB, SIS and SES respectively.

Table 1. Proximate composition of canned African giant snail meat in brine, egusi and sauce

*By difference.

\begin{tabular}{llll}
\hline Nutrient & \multicolumn{3}{l}{ Products } \\
\hline (g/100g solids)\% & SIB & SES & SIS \\
\hline Crude Protein & $84.3^{\mathrm{a}}$ & $90.1^{\mathrm{a}}$ & $89.3^{\mathrm{a}}$ \\
Crude Fat & $2.0^{\mathrm{b}}$ & $5.0^{\mathrm{c}}$ & $3.3^{\mathrm{d}}$ \\
Ash $(\%)$ & $4.8^{\mathrm{n}}$ & $1.6^{\mathrm{f}}$ & $1.5^{\mathrm{f}}$ \\
Carbohydrate* & $8.9^{\mathrm{g}}$ & $3.3^{\mathrm{h}}$ & $5.9^{\mathrm{k}}$ \\
\hline
\end{tabular}

Values with common superscript letters are not significantly $(p>0.5)$ different within each row. Data are mean of 
triplicate determinations. SIB = snail in brine, $\mathrm{SES}=$ snail in egusi soup, $\mathrm{SIS}=$ snail in sauce.

\subsection{Inoculated Pack Studies for the Canned Snail Products}

Tests for commercial sterility were carried out by inoculated pack studies. The results are presented in Table 2 . For the canned products, it can be observed that the test cans did not show any swelling unlike the control (non-heat processed) cans that were all swollen within first week of storage at $37^{\circ} \mathrm{C}$. Microbiological tests indicated that spoilage was due to Clostridium sporogenes.

Table 2. Inoculated pack tests for canned snail products at $37^{\circ} \mathrm{C}$

\begin{tabular}{|c|c|c|c|}
\hline \multicolumn{2}{|l|}{ Incubation } & \multicolumn{2}{|c|}{ Number of cans swollen } \\
\hline Time (wks) & SIB & SIS & SES \\
\hline Control & $0 / 10$ & $0 / 10$ & $0 / 10$ \\
\hline Test cans & $0 / 10$ & $0 / 10$ & $0 / 10$ \\
\hline Control & $10 / 10$ & $10 / 10$ & $10 / 10$ \\
\hline Test cans & $0 / 10$ & $0 / 10$ & $0 / 10$ \\
\hline Test cans & $0 / 10$ & $0 / 10$ & $0 / 10$ \\
\hline Test cans & $0 / 10$ & $0 / 10$ & $0 / 10$ \\
\hline 8. Test cans & $0 / 10$ & $0 / 10$ & $0 / 10$ \\
\hline
\end{tabular}

Control $=$ non heat processed cans, test cans $=$ heat processed cans

SIS = snail in brine, SIB = snail in brine, SES = snail in egusi soup.

\subsection{Sensory Properties}

Typical variance data for taste, appearance and bitterness of the canned products are shown in Tables 5,6 and 7 respectively. Since the variance ratio for sensory score for taste of the samples is smaller than tabulated (2.85) for judges, likewise for the appearance (1.27) and bitterness (1.09). There were no significant ( $p>0.05$ ) changes in sensory properties during the six months of storage.

Table 5. Analysis of variance chart for sensory score for taste of canned snail-in-brine

\begin{tabular}{lllll}
\hline Sources of variation & Df & Ss & ms & F \\
\hline Samples & 6 & 4.94 & 0.82 & 0.38 \\
Judges & 14 & 4.71 & 0.33 & 2.85 \\
Error & 84 & 179.49 & 2.13 & \\
Total & 104 & 189.14 & & \\
\hline
\end{tabular}

$\mathrm{df}=$ degree of freedom, $\mathrm{ss}=$ sum of square, $\mathrm{ms}=$ mean squares, $\mathrm{F}=$ variance ratio.

Table 6. Analysis of variance chart for sensory score of appearance of canned snail in brine

\begin{tabular}{lllll}
\hline Sources of variation & df & Ss & ms & F \\
\hline Samples & 6 & 1.84 & 0.30 & 1.66 \\
Judges & 14 & 3.24 & 0.23 & 1.27 \\
Error & 84 & 15.63 & 0.18 & \\
Total & 104 & 20.10 & & \\
\hline
\end{tabular}

$\mathrm{df}=$ degree of freedom, $\mathrm{ss}=$ sum of square, $\mathrm{ms}=$ mean squares, $\mathrm{F}=$ variance ratio.

Table 7. Analysis of variance chart for sensory score for bitterness of canned snail-in-brine

\begin{tabular}{lllll}
\hline Sources of variation & df & Ss & ms & F \\
\hline Samples & 6 & 1.66 & 0.28 & 1.27 \\
Judges & 14 & 3.35 & 0.24 & 1.09 \\
Error & 84 & 18.35 & 0.22 & \\
Total & 104 & 23.56 & & \\
\hline
\end{tabular}

$\mathrm{df}=$ degree of freedom, $\mathrm{ss}=$ sum of square, $\mathrm{ms}=$ mean squares, $\mathrm{F}=$ variance ratio. 


\subsection{Accelerated Storage Tests}

Within a period of 6 weeks, the canned snail products were subjected to temperature stress by storage at 50,60, 70 and $80^{\circ} \mathrm{C}$ respectively. During this period, the $\mathrm{pH}$ and overall acceptability of the products were determined. See tables 8 and 9 below.

Table 8. Changes in $\mathrm{pH}$ with storage time for canned snail products at elevated temperatures

\begin{tabular}{llllll}
\hline & \multicolumn{5}{l}{ Storage temperature $\left({ }^{\mathbf{0}} \mathbf{C}\right)$} \\
\hline Storage Time (weeks) & Products & \multicolumn{3}{l}{} \\
\hline & & 50 & 60 & 70 & 80 \\
1 & SIB & 6.85 & 6.80 & 6.85 & 6.86 \\
2 & & 6.74 & 6.74 & 6.74 & 6.22 \\
3 & & 6.66 & 6.62 & 6.66 & 6.07 \\
4 & & 6.58 & 6.55 & 6.58 & 5.82 \\
5 & & 6.54 & 6.51 & 6.54 & 5.64 \\
6 & & 6.48 & 6.58 & 6.48 & 5.45 \\
0 & SES & 6.42 & 6.42 & 6.92 & 5.53 \\
1 & 6.85 & 6.89 & 6.48 & 6.66 \\
2 & & 6.70 & 6.47 & 6.77 & 6.54 \\
3 & & 6.62 & 6.39 & 6.96 & 6.79 \\
4 & & 6.49 & 5.98 & 6.59 & 6.53 \\
5 & & 6.51 & 6.59 & 6.97 & 6.21 \\
6 & & 6.70 & 5.99 & 6.38 & 6.79 \\
0 & SIS & 6.78 & 6.98 & 6.39 & 6.58 \\
1 & 6.34 & 6.45 & 6.76 & 6.65 \\
2 & & 6.32 & 6.43 & 6.79 & 6.65 \\
3 & & 6.59 & 6.23 & 6.75 & 6.63 \\
4 & & 6.48 & 6.12 & 6.74 & 6.62 \\
5 & & 6.76 & 6.32 & 6.73 & 6.43 \\
6 & & 6.89 & 6.12 & 6.65 & 6.12 \\
\hline
\end{tabular}

$\mathrm{N}=4$ number of points, S.E standard error of estimate, $\mathrm{r}^{2}=$ coefficient of regression, $\mathrm{E}_{\mathrm{a}}=$ Activation energy 
Table 9. Mean overall acceptability scores for canned snail products

\begin{tabular}{llllll}
\hline & \multicolumn{5}{l}{ Storage temperature $\left({ }^{\mathbf{0}} \mathbf{C}\right)$} \\
\hline Storage Time (weeks) & Products & & & \\
\hline & & 50 & 60 & 70 & 80 \\
\hline 0 & SIB & 6.8 & 6.8 & 6.8 & 6.8 \\
1 & & 6.7 & 6.7 & 634 & 6.2 \\
2 & & 6.6 & 6.6 & 6.6 & 6.7 \\
3 & & 6.5 & 6.5 & 6.5 & 5.2 \\
4 & & 6.5 & 6.5 & 6.4 & 5.4 \\
5 & & 6.4 & 6.5 & 6.8 & 5.5 \\
6 & 6.4 & 6.4 & 6.2 & 6.2 \\
0 & SES & 6.8 & 6.0 & 6.48 & 6.6 \\
1 & & 6.7 & 6.4 & 6.77 & 6.4 \\
2 & & 6.6 & 6.3 & 6.96 & 6.9 \\
3 & & 6.4 & 5.9 & 6.59 & 6.3 \\
4 & & 6.5 & 6.9 & 6.97 & 6.1 \\
5 & & 6.7 & 5.9 & 6.38 & 6.7 \\
6 & SIS & 6.7 & 6.8 & 6.39 & 6.8 \\
0 & & 6.9 & 6.8 & 6.8 & 6.85 \\
1 & 6.65 & 6.45 & 6.54 & 6.89 \\
2 & & 6.76 & 6.11 & 6.12 & 6.70 \\
3 & & 6.99 & 6.90 & 6.09 & 6.44 \\
4 & & 6.51 & 6.40 & 6.39 & 6.09 \\
5 & & 6.43 & 6.47 & 6.45 & 6.49 \\
6 & & 6.89 & 6.79 & 6.75 & 6.44 \\
\hline
\end{tabular}

$\mathrm{N}=4$ number of points, S.E standard error of estimate, $r^{2}=$ coefficient of regression, $E_{a}=$ Activation energy

\subsection{Shelf-life Prediction}

A relationship between $\mathrm{pH}$ and overall acceptability of each product was established. The $\mathrm{pH}$ of each product was predetermined by varying the values from 6.8 to 4.5 (within low acidity range) using citric acid. The samples were then subjected to sensory evaluation on a scale with 7 as like extremely and 1 as dislike extremely. The average overall acceptability scores from a panel of 15 judges for the products are presented. These data were subjected to least square linear regression analysis to obtain relationships between $\mathrm{pH}$ and overall acceptability as provided in Table 10. The predicted shelf-lives using $\mathrm{pH}$ (via first order reaction kinetics) or overall acceptability (via zero order kinetic model) are presented in Table 10.

Table 10. Arrhenius regression derivatives for changes in $\mathrm{pH}$ of canned snail products

\begin{tabular}{llll}
\hline \multicolumn{4}{c}{ Products } \\
\hline Arrhenius & & & \\
\hline Parameter & SIB & SES & SIS \\
\hline $\mathrm{N}$ & 4 & 4 & 4 \\
$\mathrm{r}^{2}$ & 0.940 & 0.868 & 0.977 \\
$\mathrm{SE}$ & 0.08 & 0.07 & 0.05 \\
Intercept & 10.2317 & 7.3250 & 7.4885 \\
$\mathrm{~K}_{0}$ & $27.77 \times 10^{3}$ & $1.52 \times 10^{3}$ & $1.787 \times 10^{3}$ \\
Slope & -93.7997 & -71.4970 & -73.4131 \\
$\therefore \mathrm{E}_{\mathrm{a}}(\mathrm{kJ} / \mathrm{mol})$ & 0.78 & 0.59 & 0.61 \\
\hline
\end{tabular}

$\mathrm{n}=$ number of points, S.E standard error of estimate, $\mathrm{r}^{2}=$ coefficient of regression, $\mathrm{E}_{\mathrm{a}}=$ activation energy, $\mathrm{k}_{0}=$ frequency factor, SIB = snail-in-brine, SIS = snail-in-egusi soup, SES = snail-in-sauce.

\section{Conclusion}

Changes in $\mathrm{pH}$ were best described by first order kinetics $\left(\mathrm{r}^{2} \geq 0.988\right)$ while overall acceptability was best described by zero order kinetics $\left(r^{2} \geq 0.997\right)$. The reaction rate constants were then fitted with the Arrhenius kinetic model to verify temperature dependence and prediction of reaction rate constants at selected ambient 
temperatures.

Models were fitted to depict the relationship between sensory attribute of acceptability scores and changes in $\mathrm{pH}$ of the canned products.

On the assumption of a minimum sensory score of (5-like much) on a scale with 6 (like very much) and 7 (like extremely), the shelf-life of the canned products were evaluated at various ambient storage temperature. These models predicted shelf-lives of 27.6 months for Snail in brine, 27 to 25 months for Snail in egusi soup and 18 to 16 months for snail in sauce of the canned products.

\section{References}

Adams, J. B. (1978). The inactivation and regeneration of peroxidase in relation to the high temperature-short time processing of vegetables. Journal of Food Technology, 13, 281-297. https://doi.org/10.1111/j.1365-2621.1978.tb00806.x

A.O.A.C. (2010). Official Methods of Analysis. Association of Official Analytical Chemists. Washington D.C.

Ariahu, C. C., Igbabul, B. D., \& Taimiyu, L. O. (2004). Thermal processing of Nigerian freshwater molluscs. 1: Commercial sterilization of mussels in brine, sauce and egusi soup. Journal of Raw Materials Research, 1(1), 26-32.

Ariahu, C. C., Ohuoba, E. U., \& Igbabul, B. D. (2012). Process times Evaluation of African Giant Snail (Achachatina achatina) based products. Journal of Food Technology, 10(3), 77-82.

Ariahu, C. C., \& Ogunsua, A. O. (2000). Thermal Degradation Kinetics of Thiamine in Periwinkle based formulated low acidity foods. International Journal of Food Science and Technology. 315-321. https://doi.org/10.1046/j.1365-2621.2000.00366.x

Ihekoronye, A. I., \& Ngoddy, P. O. (1985). Integrated Food Science and Technology for the Tropics. Macmillan Education Publishers Limited, London. p. 165-193.

Ismail, Y. S., Rustom, Lopez-Leiva, M. W., \& Baboo, M. N. (1996). UHT-Sterilized Peanut Beverages: Kinetics of Physicochemical Changes during Storage and Shelf-life Prediction Modeling. Journal of Food Science, 61, 197-208. https://doi.org/10.1111/j.1365-2621.1996.tb14759.x

Kramer, A., \& Twigg, B. A. (1970). Quality Control for the Food Industry (3rd ed.). New York: The AVI Publishing Company Incorporated. p. 495.

Lopez, C. F. (1988). Processing Procedures for Canned Food Products. In: A Complex Course in Canning Book ii (10th ed.). Baltimore M.D., the Canning Trade.

Mohala, A. G., \& Mohammed, A. A. A. (2010). Nutritive Evaluation of Bambara Groundnuts (Vigna subterranean). Pods, Seeds and Hull as Animal Feeds. Journal of Applied Sciences Research, 6(5), 383-386.

Pearson, D. (1976). The Chemical Analysis of Foods (7th ed.). London: J.A. Churchill Publishing Company Limited. p. 618.

STATGRAPHICS. (1991). Statistical Graphics Sydty. Version 5.0. Reference Manual. Statistical Graphics Cooperation. Princeton: N.J.

Stumbo, C. R. (1973). Thermobacteriology in Food Processing (2nd ed.). San Francisco: Academic Press. p. 93-120. https://doi.org/10.1016/B978-0-12-675352-3.50016-4

Vincent, A. A. (1980). Cookery Books for the Tropics. George Allen and Unwin, London. p. 40-48.

\section{Copyrights}

Copyright for this article is retained by the author(s), with first publication rights granted to the journal.

This is an open-access article distributed under the terms and conditions of the Creative Commons Attribution license (http://creativecommons.org/licenses/by/4.0/). 